\title{
Roles of Managers and Stakeholders Perception on Solar Technology Adoption Intention: A Case of Micro, Small and Medium Enterprises (MSMEs) in Lagos State, Nigeria
}

\author{
Simon Nnaemeka Ajah $^{1} \&$ Pairote Pathranarakul ${ }^{1}$ \\ ${ }^{1}$ Graduate School of Public Administration, National Institute of Development Administration, Thailand \\ Correspondence: Simon Nnaemeka Ajah, Martin de Tours School of Management and Economics (MSME \\ Business School), Assumption University, Thailand. E-mail: sajah@au.edu; simonajarn@gmail.com
}

Received: November 12, 2021

Accepted: December 26, 2021

Online Published: December 28, 2021

doi:10.5539/jsd.v15n1p29

URL: https://doi.org/10.5539/jsd.v15n1p29

\begin{abstract}
Powers shortages is rampant in Africa of which Nigeria is not an exception and solar technology as a viable alternative source of electricity which would mitigate this problem has meted slow adoption. This study aimed to explore the impact of mindset/attitude from Theory of planned behavior (TPB), Disruptive Innovation Theory (DIA), awareness-knowledge, opportunity and barrier over managers (owners) of MSMEs intention to adopt solar technology for their businesses. A questionnaire was administrated to collect data from a sample of 400 managers (owners) of MSMEs respondents' in Lagos State, Nigeria. A multivariate technique was applied to test the hypotheses using Structural Equation Modeling (AMOS-23). The findings showed that mindset/attitude, (DIA) and opportunity have a significant impact on solar technology intention, however, awareness-knowledge and barrier were not significant. These independent variables explained $71 \%$ variance of the dependent variable intention. In addition, DIA was found to have a significant impact on opportunity, barrier and mindset/attitude however, barrier on mindset/attitude was not significant. These findings not only provide evidence for MSMEs strategic planning to ensure sustainable business growth for their businesses but also provide new knowledge to policy and decision makers, the manufacturing $\&$ installation (suppliers) companies and other stakeholders for renewable energy as a part of long term sustainable development.
\end{abstract}

Keywords: attitude, awareness-knowledge, disruptive innovation activities, intentions, opportunities-barriers solar technology

\section{Introduction}

There have been many instances or suppositions regarding the factors that motivates or hinders the small businesses and households towards the adoption of solar technology and insulation (LTD, 2006). To ensure that suitable suppliers, technicians, and government policies are designed to encourage businesses to adopt such solar technology, it is critical to know why currently the attitude and perception to use the technology is not improving despite the power supply shortages in developing countries and Nigeria in this context (Guzmán - Alfonso \& Guzmán - Cuevas, 2012). Certainly, understanding the reason why the attitude is not changing makes it possible to determine how to re-strategize by the stakeholders involved, this includes the government, the manufacturing $\&$ installation (suppliers) companies, and the MSMEs managers (owners). However, the focus here is investigating the managers (owners) of MSME's solar technology adoption intention which will be beneficial to other stakeholders as identified for effective policies from the energy consumer's perspective. LTD (2006) report noted that achieving success in solar adoption, suppliers plays a very important role because, they attribute to the level of access of the product, provide the technical assistance, create awareness and provide necessary knowledge about the product through information availability which will trigger a decision to invest in solar energy technology (Board, 2020). However, the Governments' role is nonetheless essential as well, it creates the demand for solar technology through incentives and/or obligations. The Government also plays the facilitator's role of choice by MSMEs through the provision of information and creating a conducive macro environment for businesses. Consequentially, making potential solar technology adopters aware of the benefits associated with the product and attempting to change their behavior and perception (K. K. Chen, 2014; Claudy, Garcia, \& O'Driscoll, 2015; Claudy, Peterson, \& O'driscoll, 2013; Wolske, Stern, \& Dietz, 2017) and providing fiscal channels for instance, the application of tax reductions and subsidies to promote the technology as a viable alternative energy source is vital 
(Emodi \& Ebele, 2016). These two stakeholders' roles might be lacking, or that the public are not aware, or knowledgeable about solar technology in the Nigerian context, and it is imperative to understand the attitude and perception of the consumers in other to move the alternative energy supply forward in the country.

\subsection{Problem Statement}

Nigeria is the largest economy in African (Abdullahi, Renukappa, Suresh, \& Oloke, 2021) but still struggling to supply power needed for her populace to thrive further. According to Suanmali, Kokuenkan, Lohananthachai, Kumpong, and Suwatanapornchai (2018), from their Thai standpoint, a stable power supply is a necessity for business and everyday life in the twenty-first century. The authors argued that power generation supplied to the grid which are mostly non-renewable energy source is insufficient to meet the demands of the increasing urban population who are in dire need of electricity for both business activities and for their homes. This insufficient power supply will eventually lead to a search for renewable energy as an alternative (Damasen I Paul \& Uhomoibhi, 2012; Damasen Ikwaba Paul \& Uhomoibhi, 2014). The dimensions (issues) of MSMEs solar technology adoption in Nigeria in the context of this research are three-folds, economic \& social impact on one hand and sustainable development on the other.

Firstly, from the economic impact perspective, the MSMEs remains the growth engine of any economy and Nigeria is no exception, with $96 \%$ of the local businesses classified as SMEs according to International Finance Corporation (IFC). The economic activities by MSMEs play a vital role to the development and economic growth (Schumpeter, 2017). "As a middle-income country, Nigeria is increasing in agriculture, manufacturing, service, financial, technology, communications, and entertainment industries expansion", however, the country is still facing enormous economic problems which include but not limited to infrastructural development particularly power supply Ebitu, Glory, and Alfred (2016). Electricity supply has become a cog in the wheel of progress of the Nigerian economy, negatively impacting every aspect of life of the Nigerian people; their ability to carry out their daily activities and business activities (large or small). This is evident from the 2020 World Bank Doing Business report that ranked Nigeria 171 out of 190 countries in getting electricity and electricity access is seen as one of the major constraints for the private sector. According to Worldbank.org ${ }^{1}$ estimates, "around $43 \%$ of Nigerian population ( 85 million Nigerians) have no access to grid electricity, making the country the biggest energy access deficit in the world". This electricity deficit has created a significant constraint for Nigerian businesses particularly the MSMEs and ordinary citizens. This result in "annual economic losses equivalent to about $2 \%$ of GDP in the amount of $\$ 10.1$ trillion ( $\$ 26.2$ billion) as estimated by world bank". MSMEs need power to operate their business office equipment and accessories for instance, processing plants, salons, restaurants, tailoring shops etc. need electricity to survive. Ezennaya, Isaac, Okolie, and Ezeanyim (2014) predicted that Nigeria should be generating around 20,000 megawatts to meet the demand of electricity in the country, however, the country produces only about 4,000 megawatts of electricity presently resulting in shortage of power and making it difficult and practically impossible for small businesses to perform efficiently. Notwithstanding these facts that MSMEs are an important apparatus for development, economic growth and employment creation in Nigeria, poor absorptive power infrastructure and limited funds have been identified as the pinnacle factors that has hampered the development of MSMEs (Taiwo, Ayodeji, \& Yusuf, 2012).

Secondly, social impact is the effect of renewable energy to MSMEs and individuals in Nigeria in terms of the benefits. Social impact is defined by Sheikh, Kocaoglu, and Lutzenhiser (2016) as "the consequences of human populations of any public or private actions that alter the ways in which people live, work, play, relate to one another, organize to meet their needs and generally cope as member of society". Sakolsatayatorn (2018) noted that society are impacted by the renewable energy policies which influences the MSMEs adoption intention decisions. Sheikh et al. (2016) asserted that social impact factors like public behavior, their attitude or perception influences renewable energy adoption intention. All these notions from way of life and perceptions have altered the solar technology adoption intention because it is deeply interwoven. The public have negative view on solar technology, and some are unaware of its benefits, and this creates a mismatch of information between stakeholders. So, this research intended to incorporate this factor to explore from this perspective, the influence on predicting solar technology adoption intention in the context of Nigeria.

Thirdly, from sustainable development perspective, energy is the most essential issues for sustainable development (Oyedepo, 2014). According to Bazmi and Zahedi (2011) "Sustainable development is a changing process, circuiting investment, orientating technology and institution for compatible with the needs of the present and the future". The overall improvement of economic issue, social, and political structures as mentioned earlier, needs to

\footnotetext{
1 https://www.worldbank.org/en/news/press-release/2021/02/05/nigeria-to-improve-electricity-access-and-services-to-citizens (Accessed, October 29, 2021)
} 
go along with sustainability plan as a master architecture for lasting solutions to energy crisis of Nigeria (SDGs No. 7 - Affordable and clean energy, UN Assembly, 2015). According to United Nations Facts Sheet on Climate Change (UN, 2006 ${ }^{2}$ ), Africa is the most vulnerable among all the continents to the impact and risks of climate change. These risks and impact are as a result of increasing energy demand (Alabi, Ackah, \& Lartey, 2017) for business purposes and households consumption. Although it is important to emphasis that, Africa is not a significant source of greenhouse gas emission, they are to adopt the mechanisms that promotes greener products (e.g., solar technology) for sustainable growth (UNFCCC). Acknowledging the solar energy technology growth is vital for sustainable growth in Africa, as the continent is on the crossroads of poor energy provision. More than 620 million people have been estimated in Sub-Saharan Africa to have no access to steady and uninterrupted electricity for business or households' purposes (An African Energy Industry Report, 2018 ${ }^{3}$ ). This vacuum has resulted in people sourcing for energy alternatives that are available and economically efficient. Evidently, (e.g., Bachtiar, 2006; Loveldy, Ismail, \& Jubaedah, 2021) stated that solar technology has been acknowledged to be safe, boundless, and non-polluting reliable alternative energy source. However, despite advances in technology, in Nigeria, Micro, Small and Medium Enterprises (MSME's) still rely heavily on fossil fuel stand-alone generator for electricity source. Although investment in solar technology is rapidly growing and the importance of the adoption intention could never have been more emphasized for all the problems identified in this study. Reliance on fossil fuel generating set is not a sustainable source of electricity and certainly not efficient. A sustainable source of energy like solar technology provides energy that are environmentally friendly, more efficient, and economically viable as it meets the present energy needs without compromising the future needs (Stritih et al., 2015). Therefore, from these perspectives, power shortage in Nigeria is affecting business activities, so adopting solar technology as an alternative source of electricity is vital. However, from Global Market Outlook: Europe (2017), Africa and Nigeria in particular are not embracing the solar technology despite the advancement in the battery and cheaper cost. Hence, it is imperative to understand the attitude and perception, knowledge-awareness, perceived opportunities or barriers and the role of disruptive innovation activities of the MSMEs managers (owners) as energy consumers towards solar energy technology adoption intention and provide recommendations to the stakeholders concerned.

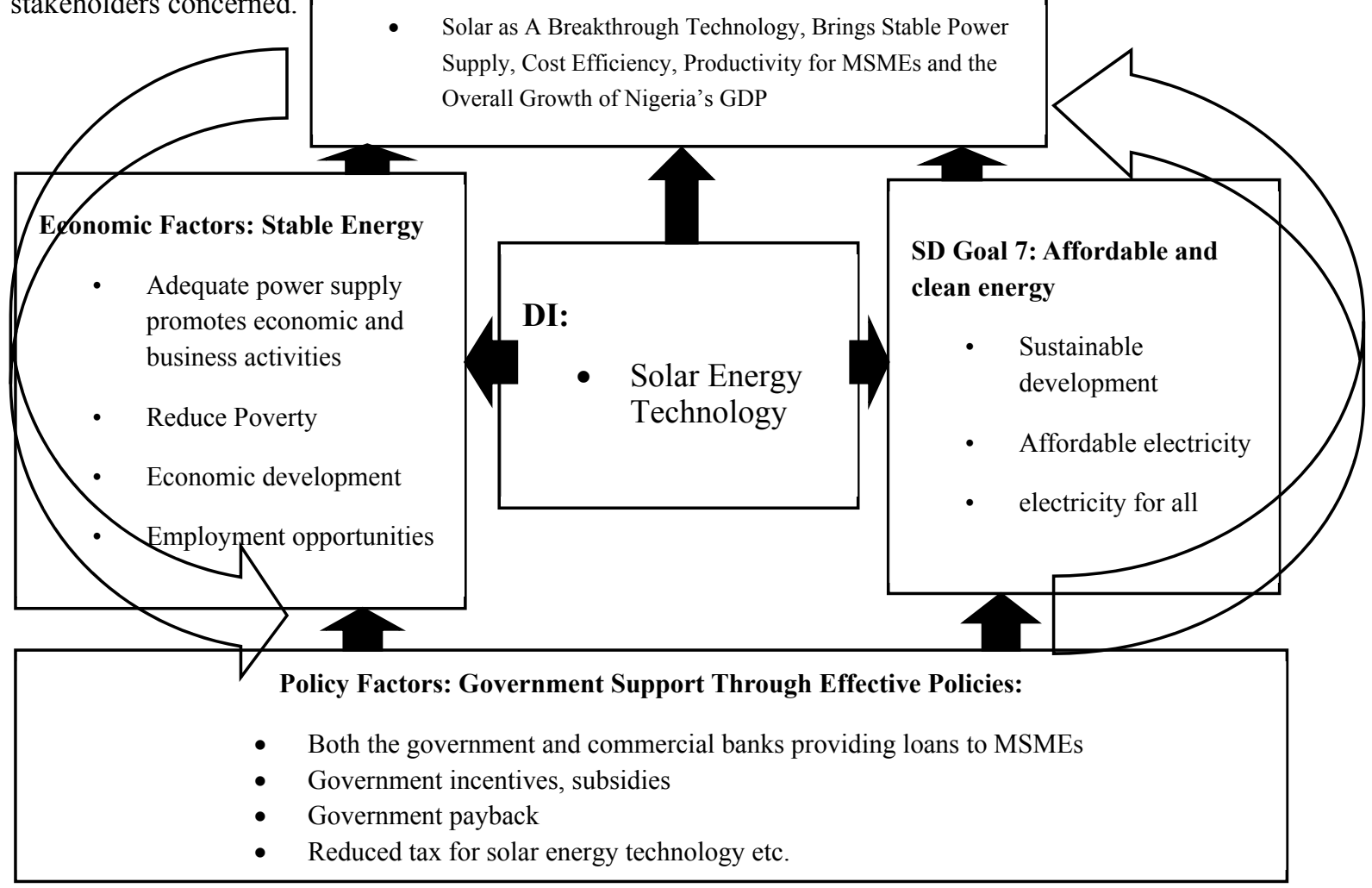

Figure 1. The author's own elaboration. Vicious cycle: Mutual benefits through effective policy on solar technology

\footnotetext{
2 https://unfccc.int/sites/default/files/resource/docs/2006/cop12/eng/05a01.pdf (Accessed on October 29, 2021)

${ }^{3}$ https://africa-energy-portal.org/reports/african-energy-industry-report-2018 (Accessed October 29, 2021)
} 


\subsection{The Significance of the Study}

Several scholars have contributed to this area of research. Many have studied the attitude, perception, knowledge $\&$ awareness, environmental and economic factors etc. and intention (Alam et al., 2014; Kim, Park, Kwon, Ohm, $\&$ Chang, 2014; Loveldy et al., 2021). Several others have also studied disruptive innovation as a motivating factor of intention (Amuzu-Sefordzi, Martinus, Tschakert, \& Wills, 2018; J. Chen, Zhu, \& Zhang, 2017; Muza \& Debnath, 2021; Petzold, Landinez, \& Baaken, 2019). However almost all the previous studies focused on household's solar adoption only. Few literatures have been done on disruptive innovation technology as a motivating factor of intention. In response to this research gap, this present study combines the behavioral factors, the social factors from government policies, as well as the disruptive innovation factor on intention of MSMEs managers (owners) based on the business level rather than households. Additionally, most of the literatures about disruptive innovation and intention to adopt solar technology were conducted using qualitative research method. This present research used quantitative research method to contribute empirically to the ongoing literature. Furthermore, limited studies have been done on the opportunities (reasons to adopt) or barrier (reason against adoption) of solar technology in Nigeria, these are all the areas that this present research aimed to cover and contributed to the ongoing literature. Moreover, (e.g., Claudy et al., 2013; Kim et al., 2014; Loveldy et al., 2021; Yergin, 2012) emphasized the importance of further studies on solar technology adoption intention to understand the potential users' perceptions and reasons to or not to adopt solar energy technology.

\subsection{The Features of MSMEs in Lagos State Nigeria}

MSMEs are imperative for economic development, growth, and job creation which needed a robust support for sustainable development and for improving the living standards and poverty alleviation (Ebitu et al., 2016).

Table 1. MSME categories in Nigeria

\begin{tabular}{llll}
\hline & Size Category & Employment & $\begin{array}{l}\text { Assets (NGN=Million) (Excluding } \\
\text { land and buildings) }\end{array}$ \\
\hline 1 & Micro enterprises & Less than 10 & Less than 5 \\
2 & Small enterprises & 10 to 49 & 5 to less than 50 \\
3 & Medium enterprises & 50 to 199 & 50 to less than 500 \\
\hline
\end{tabular}

Source: Adapted from SMEDAN (2013).

The scope of this study Lagos State is the smallest in Nigeria hitherto, but it has the highest urban population. Based on the "4N-Habitat and international development agencies estimates", Lagos State has around 24.6 million people in 2015. According to lagosstate.gov.ng", "the population of the state is growing 10 times faster than that of 32 African nations population combined, New York and Los Angeles". Lagos State is Nigeria's commercial hub and it remains the focal point of economic activities as it plays a pivotal role in the Nigerian economy. The Gross Domestic Product (GDP) of Lagos is reported to be around $26.7 \%$ of total GDP which is NGN27.125trillion (\$145.141billion in monitory terms) in 2016 according to Lagos Bureau of Statistics. The estimated number of MSMEs in Nigeria is at 36,994,578 with a total employment of 57,836,391 and contributing $46.54 \%$ to the GDP in nominal terms. Among these indicators, only Lagos State contributes roughly $27 \%$ to GDP with 3,224,324 million MSMEs businesses in the State which employed 5,577,011 million people according to (Ebitu et al., 2016; SMEDAN, 2013). These are the considerations for using Lagos State to study the managers (owners) attitude-behavior and motivational factors to adopt solar technology for their MSMEs businesses in Nigeria.

\subsection{Literature Review and Background}

\subsubsection{An Overview of Solar Technology in Nigeria}

Nigeria and most African countries are located near the equator, making solar system an attractive alternative energy source (Aliyu, Dada, \& Adam, 2015). Solar technology can be a singular solution to the world's energy need and the trend of installation is increasing elsewhere apart from Africa (Global Market Outlook: Europe, 2017). Solar technology is even more suitable for Nigeria's energy needs as almost all renewable energies originated

\footnotetext{
${ }^{4}$ https://unhabitat.org/nigeria

${ }^{5}$ http://mepb.lagosstate.gov.ng; https://lagosstate.gov.ng/about-lagos
} 
directly or indirectly from the sun (Ohunakin, Adaramola, Oyewola, \& Fagbenle, 2014). This study focused on "Photovoltaic systems" (PV) that converts sunlight to electricity. This kind of solar energy system is installed on top of the building's roof generally to generate power for businesses and households. The benefits of solar technology are numerous for instance, it provides a proven source of electricity using technology that has no emissions in operation, and it is readily used in urban environments without requiring additional land use which is good for MSMEs who mostly use rented spaces (Faiers, 2009). Solar power in Nigeria is gaining market momentum although it is relatively new, only forward-looking businesses have been able to identify and capture the opportunity for their business. Nigeria is in a region where sunlight is distributed evenly throughout the year (Ohunakin et al., 2014). According to Ohunakin et al. (2014) the estimate of "annual daily average of total solar radiation varies from about $12.6 \mathrm{MJ} / \mathrm{m} 2 /$ day $(3.5 \mathrm{kWh} / \mathrm{m} 2 /$ day $)$ in the coastal region to about $25.2 \mathrm{MJ} / \mathrm{m} 2 /$ day $(7.0$ $\mathrm{kWh} / \mathrm{m} 2 /$ day) in the far north, thus making her to have an estimated 17,459,215.2 million MJ/day (17.439 TJ/day) of solar energy falling on its $923,768 \mathrm{~km} 2$ land area". "Provided there is an estimated average of $18.9 \mathrm{MJ} / \mathrm{m} 2 / \mathrm{day}$ $(5.3 \mathrm{kWh} / \mathrm{m} 2 /$ day) over a whole year, an average of 6,372,613 PJ/year (E1770 thousand Tw/year) of solar energy is estimated to fall on the entire land area" (ibid). From these information, Nigeria has sufficient solar radiation to generate viable electricity for both businesses and households usage (Ugulu \& Aigbayboa, 2019).

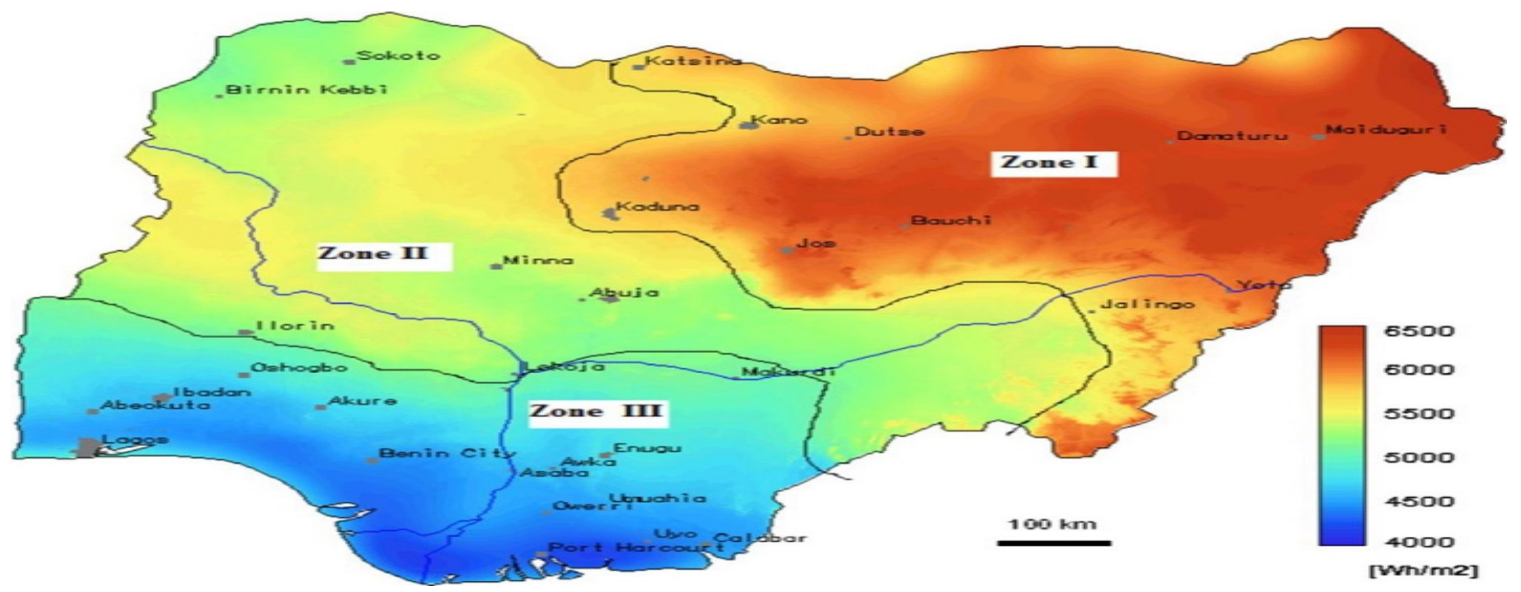

Figure 2. Zone based solar radiation map of Nigeria Adapted from (Aliyu et al., 2015)

\subsubsection{Political and Social Challenges in the Energy Sector of Nigeria}

The enormous energy supply problems faced by Nigerians is insurmountable. The government's inability to show commitment through effective policies to stimulate and encourage more private investment into the energy sector is alarming (Doe \& Emmanuel, 2014; Mkhwanazi, 2003). Policies can create opportunities or barriers through government political will, legislative, regulatory, and legal issues governing renewable energies. To emphasize on political issues in the energy sector, (e.g., Abdullahi et al., 2021) noted that the political will through policies for good governance and frameworks to drive the potential solar technological elements into reality is lacking. Nigeria's political elites have conflicting interest in developing and managing alternative sources of power especially renewable energy like solar technology, as a result, the adoption of the technology on a large scale project by the government is low (Ozoegwu, Mgbemene, \& Ozor, 2017). 
Table 2. Key actors engaged in the Nigerian energy sector

\begin{tabular}{ll}
\hline Actor group & \multicolumn{1}{c}{ Details } \\
\hline Donors and NGO's & They are supporting the implementation of solar programs in Nigeria (e.g., \\
& USaids.gov and World Bank) \\
& MSMEs businesses, households, solar companies. Also, private actors in the \\
wider electrical subsector (e.g., private distribution company, generators, & \\
& etc.) \\
Government officials promoting increased electrical usage through \\
decentralized solar technology and grid extension. Also, they are the energy \\
regulatory body. Government micro-finance institutions providing loans to \\
potential solar technology adopters \\
Researchers from different universities and scholars exploring this topic and \\
promoting the use of solar technology in Nigeria
\end{tabular}

\subsubsection{Theoretical Background and Conceptual Model}

Different theories like the theory of planned behavior (TPB), innovation diffusion theory (IDT), theory of rational action (TRA) etc. have been adopted by different scholars to examine the behavioral and psychological factors affecting the public solar technology adoption intention. The Theory of Planned Behavior (TPB) and Disruptive Innovation Theory (DIT) and other variables derived from literature were adopted and integrated to examine MSMEs manager's (owner's) intention towards adoption of solar technology in Lagos State, Nigeria. This section explored all the variable adopted in this study. In this regard, the concept of solar technology adoption intention, according to Hai (2021) refers to "a course of action or plan that an actor considers necessary, and thus intends to undertake to accomplish a certain behavior". Faiers (2009) stated that "the adoption of innovations is a point in time when the adopter of an innovation decides to use the innovation in question". Intention is defined as a motivational factor and willingness of a person to engage in certain behavior (Ajzen \& Fishbein, 2005). Attitude towards solar technology from theory of planned behavior (TPB) is defined as "the perceived level of positive and negative impressions toward acting on the particular behavior" (Ajzen \& Fishbein, 2005). They stated that attitude is a predisposition learned to respond in a certain way either as favorable or unfavorable to a given object. For businesses and policy decision-makers, understanding the factors and the psychological processes of the attitude towards solar renewable energy adoption is vital (Claudy et al., 2013). Jorns (2020) and Kim et al. (2014) found attitude towards solar technology have a positive relationship adoption intention. From policy support and perceived benefits as opportunities, Emodi and Ebele (2016) noted that opportunity to adopt solar technology is influenced by many factors including; government regulations, capital investment, fiscal incentives and policy strategy as environmental support programs. Scholars have identified benefits as a key factor that influence solar technology adoption intention. For instance, Caird, Roy, and Herring (2008) stated that the adopters of renewable solar energy do so for many reasons; they found that the main drivers of adoption intention were saving energy, reducing fuel bills and concern for the environment. Loveldy et al. (2021) also found reasons for (or against) solar technology adoption to significantly impact attitude towards behavior and intention. In addition, lack of policy support and perceived cost as barriers have been one of the major component in solar adoption intention. Despite the significant advancement in solar technology that reduces the overall cost, the up-front (initial and maintenance cost) payment is still considered to be a barrier according to (Board, 2020) especially to micro and small businesses in a financially constrained economy like Nigeria. Loveldy et al. (2021) noted that potential solar technology adopters may decide to adopt or not the technology due to the lack of funds. The MSME's who are the end users of renewable solar energy technology in this present study encounters different challenges in accessing credits and the limited availability of micro financing both from the government and commercial institutions in Nigeria. If smaller businesses intend to adopt solar technology using credit financing, they are faced with high interest rates and unsupportive vendors who by themselves are also facing similar barrier (Efurumibe, 2013). Reddy and Painuly (2004) found that financial (perceived cost) and economic barrier, institutional and regulatory barrier, and awareness and information barrier affect adoption intention.

Awareness-knowledge of solar technology is defined as "the degree to which users are conscious of the current new technology benefits and its weaknesses and they can keep track of updates on new technologies" (Board, 
2020). Awareness-knowledge plays a key role in technology adoption, for instance, Rogers and Shoemaker (2001) postulated that consumers go through "a series of processes in knowledge, conviction, decision and confirmation before they are ready to adopt a new product or service". Several studies found that awareness-knowledge influence adoption intention (Alam et al., 2014; Board, 2020; Rezaei \& Ghofranfarid, 2018). Rezaei and Ghofranfarid (2018) found a positive relationship between knowledge-awareness and adoption intention. Finally, disruptive innovation (DI) is defined as "a technology, product or process that creeps up from below an existing business and threatens to displace it" (Christensen \& Bower, 1996). Thomond, Herzberg, and Lettice (2003) stated that "disruptive innovation, disruptive technologies and disruptive business strategies are emerging and increasingly becoming a prominent business term that are used to describe a form of revolutionary change". Sadiq, Hussain, and Naseem (2020) indicated that DI can change the market status que dramatically and overturn the incumbents by creating new market dynamics. DI technology as having an influence on managers (owners) of MSME's perception to adopt solar technology because of their perceived intrinsic value for operational efficiency and effectiveness rather than the bubble (Siegel, 2003). DI technology can either be perceived as an opportunity or threat to MSMEs businesses depending on the disruptive innovation activities of the business manager (owner). In this sense, if managers (owners) recognized DI as an opportunity with potential benefits to his or her business, it motivates and gives the managers (owners) reason(s) to adopt solar technology and vice versa. Sadiq et al. (2020) defined disruptive innovation activities (DIA) as a synchronize and focused efforts that strain on exploiting or at least initiating the DI process. Both internal and external factors have influenced managers (owners) of MSMEs DIA. The external factor indicates government support through the introduction of favorable innovative environment and the internal factors is the personality attributes, technology inclination and the willingness to adopt innovative product. Moreover, Sadiq and Hussain (2018) emphasized that managers (owners) of MSMEs DIA are anticipated to nurture and generate DI. The research model and the hypotheses relationships are given in Figure 3:

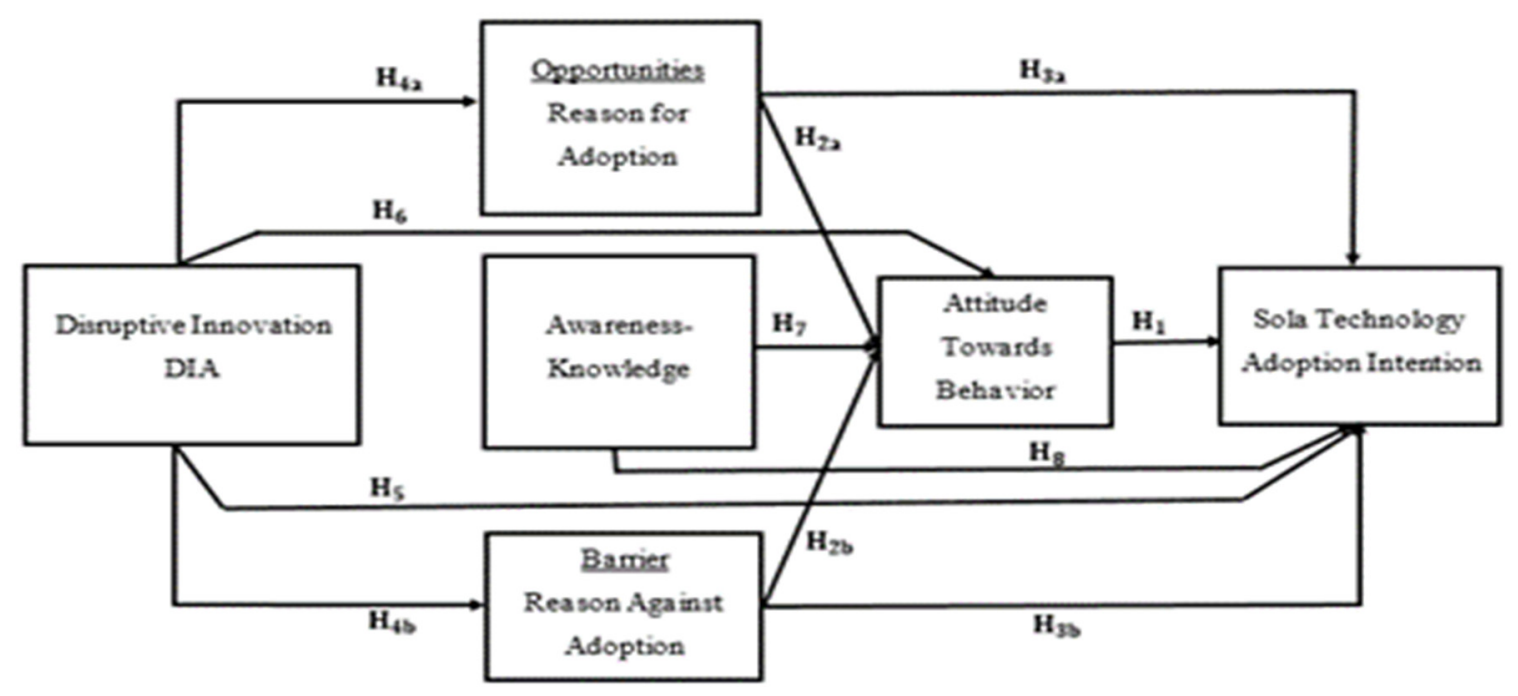

Figure 3. The proposed model of the study

\section{Method}

\subsection{Research Design Target Population and Pilot Testing}

A research strategy is the overall coordination of how the research is conducted which can be based on either a quantitative or a qualitative strategy (Bell, Bryman, \& Harley, 2018; Bryman, 2006). Therefore, a quantitative method was adopted using a cross-sectional survey where data was collected at one point in time. According to (Zikmund, Babin, Carr, \& Griffin, 2003) cross-sectional survey required less period of time and cost efficient when compared to longitudinal study. Target population for this study consisted of the managers (owners) of micro, small and medium enterprises (MSMEs) in Lagos State Nigeria which is estimated at 5,577,011 (SMEDAN, 2013). Pilot testing was performed where the researcher asked fifty managers (owners) about the timing, how difficult it was to understand the questions and their feedback about the survey and from the feedbacks obtained and revised, the research instruments was finalized. Babbie (2013) recommended a minimum of thirty respondents for pilot 
testing. A total 450 questionnaires were collected through an online survey, however, after removing the outliers using Mahalanobis distance (Mahalanobis, 1936), 400 survey responses were used for the data analysis after the data cleaning process. The datasets contained no missing data as respondents could not submit the survey unless they have filled in all the questions in the questionnaire. Data collected includes seven parts relating to the profile information questions and intention, attitude, opportunities, barrier, awareness-knowledge, and DIA measurements. The measured items are presented in Table. 3 with the sources. Managers (owners) were asked to identify their opinion on each item of 5-point Likert scale as follows: 1= "strongly disagree"; $2=$ "disagree"; $3=$ "neither agree nor disagree"; 4= "agree"; and 5= "strongly agree".

\subsection{Sampling Procedures and Sample Size}

Sampling procedure is the process of selecting a set of individuals able to represent the whole population from the targeted population that the proponent wished study (McDonald, Gan, Fraser, Oke, \& Anderson, 2015). The sampling technique are classified as probability or non-probability (Saunders, Lewis, \& Thornhill, 2016). A sample size of 400 MSMEs managers (owners) were chosen using convenience sampling from non-probability technique because random sampling was not feasible for the scope which makes other research methods impractical (Creswell \& Creswell, 2017). Yamane (1967) formula is used to calculate the sample size because the population is finite and known.

The formula is given:

$$
n=\frac{N}{1+N(e)^{2}}
$$

- ' $n$ ' is the sample size

- ' $\mathrm{N}$ ' is the population size

- ' $\mathrm{e}$ ' is the level of precision or level significance (limit of tolerable error)

- ' 1 ' = unity (constant)

$$
n=\frac{N}{1+N(e)^{2}}=n=\frac{5,577,011}{1+5,577,011(0.05)^{2}}=400
$$

\subsection{Measurement of Validity, Reliability and Covariates}

To confirm the measurements used in this research, a face validity and construct validity which includes discriminant validity and convergent validity were examined. The face validity of the questionnaire was confirmed by the faculty members at National Institute of Development Administration (NIDA) and NIDA ethical committees. Whereas the construct validity and the convergent validity were confirmed through confirmatory factor loadings (CFA) greater than 0.5 , the average variance extracted (AVE) higher than 0.5 , and composite reliability (CR) bigger than 0.7 as suggested by (Hair Jr, Hult, Ringle, \& Sarstedt, 2021). The discriminant validity was examined by comparing "the square root of average variance extracted (AVE) with the correlation of itself to other variables" (ibid). "The square root of AVE of the construct has to be greater than any correlation that is involved". Regarding the CR and AVE see Figure.4, the CFA see Table. 3 \& Figure. 5 and the overall model goodness of fit, various indices were employed in this research see Table.4. The model fit criteria was adopted from Meyers, Gamst, and Guarino (2016, p. 559) and Graphic Software of AMOS-23 was used to analyze the data. The chi-square test is sensitive to sample size, however if the model degree of freedom otherwise known as the relative chi-square did not exceed 5.0 it would be assumed to demonstrate a reasonable fit (Kline, 2015). All of these criteria were met, hence, no issue of validity and reliability in the construct. 


\begin{tabular}{|c|c|c|c|c|c|c|c|c|c|c|}
\hline & CR & AVE & MSV & MaxR(H) & Attitude & Opportunity & Barrier & Intention & Awareness & DLA \\
\hline Attitude & 0.960 & 0.828 & 0.642 & 0.972 & $\mathbf{0 . 9 1 0}$ & & & & & \\
\hline Opportunity & 0.993 & 0.966 & 0.466 & 0.995 & $0.537 * *$ & $\mathbf{0 . 9 8 3}$ & & & & \\
\hline Barrier & 0.840 & 0.650 & 0.463 & 1.099 & $0.411 * *$ & $0.578 * * *$ & $\mathbf{0 . 8 0 6}$ & & & \\
\hline Intention & 0.975 & 0.888 & 0.642 & 0.982 & $0.801 * * *$ & $0.641 * * *$ & $0.390 * * *$ & $\mathbf{0 . 9 4 2}$ & & \\
\hline Awareness & 0.846 & 0.660 & 0.550 & 0.948 & $0.742 * * *$ & $0.369 * \cdots *$ & $0.296 * *$ & $0.573 * * *$ & $\mathbf{0 . 8 1 2}$ & \\
\hline DLA & 0.899 & 0.696 & 0.466 & 0.960 & $0.577 * * *$ & $0.683 * * *$ & $0.680 * * *$ & $0.513 * * *$ & $0.461 * * *$ & $\mathbf{0 . 8 3 4}$ \\
\hline
\end{tabular}

\section{Validity Concerns}

No validity concerns here.

Figure 4. Model of Validity Measures

Note: Significance of Correlations: $\dagger \mathrm{p}<0.100,{ }^{*} \mathrm{p}<0.050, * * \mathrm{p}<0.010, * * * \mathrm{p}<0.001$

$\mathrm{Hu}$ and Bentler (1999): "Cutoff Criteria for Fit Indexes in Covariance Structure Analysis: Conventional Criteria Versus New Alternatives" SEM. Extracted from Gaskin and Lim (2016) "Master Validity Tool", AMOS Plugin.

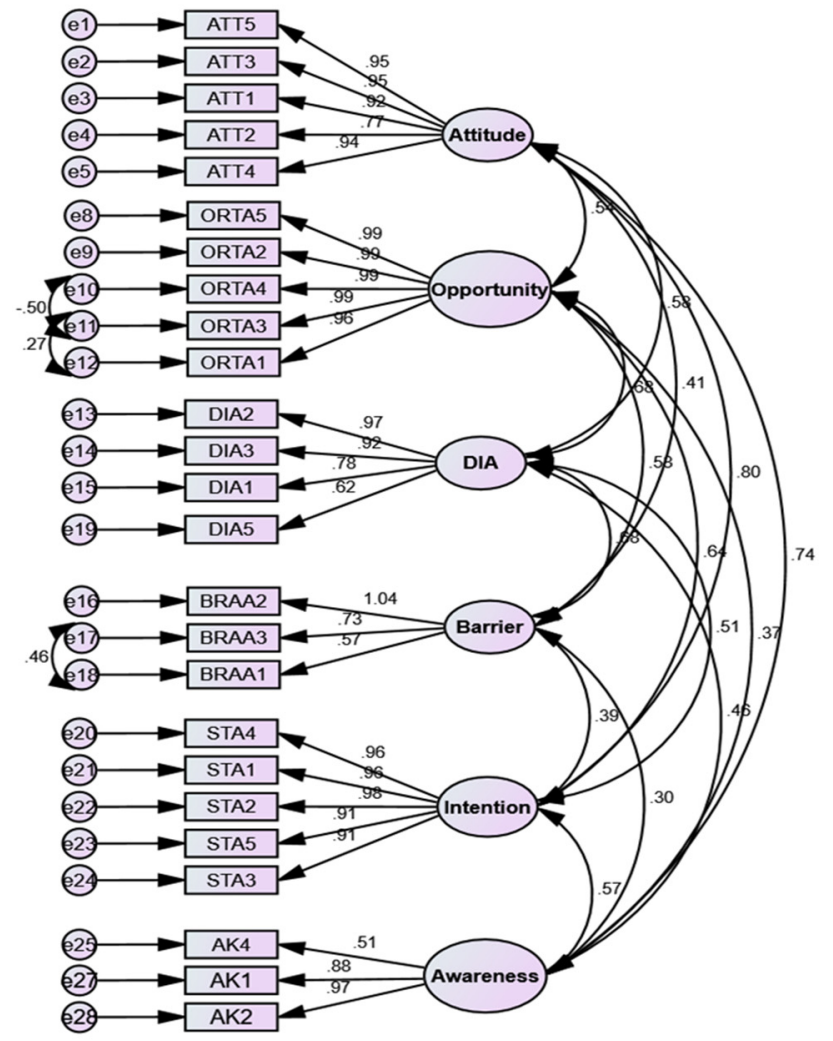

Figure 5. CFA Standardized Regression Weights Extracted from AMOS-23

Note: Goodness-of-fit statistics: Relative chi-square $=4.594$; GFI $=0.828, \mathrm{AGFI}=0.783, \mathrm{CFI}=0.940$, IFI $=0.940$, $\mathrm{PCFI}=0.805, \mathrm{PNFI}=0.792, \mathrm{RMSEA}=0.095, \mathrm{SRMR}=0.040$. 
Table 3. The combined factor loadings (CFA) of all variables extracted (AMOS-23)

\begin{tabular}{|c|c|c|}
\hline & Latent and Observed Variables & $\begin{array}{c}\text { Estimate: } \\
\text { Standardized Factor } \\
\text { Loadings } \\
\end{array}$ \\
\hline & $\begin{array}{l}\text { Awareness-Knowledge: (Reddy \& Painuly, 2004), (Parsad, Mittal, } \\
\& \text { Krishnankutty, 2020); (Alam et al., 2014); (Jorns, 2020); } \\
(\mathrm{AVE}=0.660, \mathrm{CR}=0.846, \mathrm{MSV}=0.550, \operatorname{MaxR}(\mathrm{H})=0.948)\end{array}$ & \\
\hline AK1 & I am aware of solar technology & 0.88 \\
\hline AK2 & $\begin{array}{l}\text { I am aware of the need to adopt and use solar technology for my } \\
\text { business }\end{array}$ & 0.97 \\
\hline AK3 & I know the companies to consult for installation of solar technology & Dropped \\
\hline AK4 & $\begin{array}{l}\text { I can find information on how to understand the benefits of solar } \\
\text { technology }\end{array}$ & 0.51 \\
\hline \multirow[t]{2}{*}{ AK5 } & $\begin{array}{l}\text { I have enough simple information about solar technology that makes } \\
\text { it easy for me to use solar technology }\end{array}$ & Dropped \\
\hline & $\begin{array}{l}\text { Attitude: (Kim et al., 2014; Loveldy et al., 2021); (Park \& Ohm, } \\
\text { 2014); (Rezaei \& Ghofranfarid, 2018); (Jorns, 2020); (AVE }=0.828 \text {, } \\
\mathrm{CR}=0.960, \operatorname{MSV}=0.642, \operatorname{MaxR}(\mathrm{H})=0.972)\end{array}$ & \\
\hline ATT1 & Adopting solar technology is a good thing & 0.92 \\
\hline ATT2 & $\begin{array}{l}\text { I would pay additional money to receive energy through solar } \\
\text { technology }\end{array}$ & 0.77 \\
\hline ATT3 & Solar technology would be useful for my business & 0.95 \\
\hline ATT4 & I have positive feeling towards solar technology in general & 0.93 \\
\hline \multirow[t]{2}{*}{ ATT5 } & Solar technology will add a lot of value to my business & 0.95 \\
\hline & $\begin{array}{l}\text { Barrier: (Jorns, 2020; Loveldy et al., 2021), (Parsad et al., 2020); } \\
\text { (Caird et al., 2008; Walters, Kaminsky, \& Huepe, 2018) (Schwarz, } \\
\text { Wdowiak, Almer - Jarz, \& Breitenecker, 2009); (AVE }=0.650 \text {, } \\
\text { CR }=0.840, \text { MSV }=0.463, \operatorname{MaxR}(H)=1.099)\end{array}$ & \\
\hline BRAA1 & The initial installation cost will be too high for my business & 0.574 \\
\hline BRAA2 & $\begin{array}{l}\text { There are insufficient funds from both the government and } \\
\text { commercial banks available for MSMEs businesses }\end{array}$ & 1.042 \\
\hline BRAA3 & It requires additional effort and time to install solar technology & 0.731 \\
\hline \multirow[t]{2}{*}{ BRAA4 } & $\begin{array}{l}\text { I'm worried about how much maintenance costs will be needed in } \\
\text { the future }\end{array}$ & Dropped \\
\hline & $\begin{array}{l}\text { DIA: }(\text { Sadiq et al., 2020); }(\mathrm{AVE}=0.696, \mathrm{CR}=0.899, \mathrm{MSV}=0.466 \text {, } \\
\operatorname{MaxR}(\mathrm{H})=0.960)\end{array}$ & \\
\hline DIA1 & $\begin{array}{l}\text { I am interested in activities which help to make my business } \\
\text { gradually attractive to customers }\end{array}$ & 0.779 \\
\hline DIA2 & $\begin{array}{l}\text { I am interested in activities which help my business to discover and } \\
\text { address the needs of customers }\end{array}$ & 0.971 \\
\hline DIA3 & $\begin{array}{l}\text { I am interested in activities which try to proactively change my } \\
\text { customer's tastes and preferences towards my business }\end{array}$ & 0.921 \\
\hline DIA4 & $\begin{array}{l}\text { My business lags in making efforts to introduce disruptive products } \\
\text { like solar technology }\end{array}$ & Dropped \\
\hline \multirow[t]{2}{*}{ DIA5 } & $\begin{array}{l}\text { I always exert efforts to introduce disruptive innovative products or } \\
\text { services to my business }\end{array}$ & 0.622 \\
\hline & $\begin{array}{l}\text { Opportunity: (Jorns, 2020; Loveldy et al., 2021), (Parsad et al., } \\
\text { 2020); (Caird et al., 2008; Walters et al., 2018) (Schwarz et al., } \\
\text { 2009); (AVE }=0.966, \mathrm{CR}=0.993, \mathrm{MSV}=0.466, \operatorname{MaxR}(\mathrm{H})=0.995)\end{array}$ & \\
\hline ORTA1 & $\begin{array}{l}\text { Solar technology will significantly reduce the monthly electricity bill } \\
\text { for my business }\end{array}$ & 0.957 \\
\hline ORTA2 & $\begin{array}{l}\text { Solar technology will give my business return capital and make a } \\
\text { profit }\end{array}$ & 0.993 \\
\hline ORTA3 & $\begin{array}{l}\text { Solar technology makes me self-sufficient in my own electricity } \\
\text { needs }\end{array}$ & 0.986 \\
\hline
\end{tabular}




\section{Latent and Observed Variables}

\begin{tabular}{|c|c|c|}
\hline & & Loadings \\
\hline ORTA4 & $\begin{array}{l}\text { Solar technology will help my business to reduce the use of fossil } \\
\text { fuels to power stand-alone generator }\end{array}$ & 0.986 \\
\hline \multirow[t]{2}{*}{ ORTA5 } & $\begin{array}{l}\text { Solar technology will make my business independent from the } \\
\text { national electricity provider }\end{array}$ & 0.993 \\
\hline & $\begin{array}{l}\text { Intention: (Kim et al., 2014; Loveldy et al., 2021), (K. K. Chen, } \\
\text { 2014), (Park \& Ohm, 2014); (Jorns, 2020); (AVE=0.888, } \\
\mathrm{CR}=0.975, \mathrm{MSV}=0.642, \operatorname{MaxR}(\mathrm{H})=0.982)\end{array}$ & \\
\hline STA1 & I intend to use solar technology if access is available & 0.957 \\
\hline STA2 & $\begin{array}{l}\text { I intend to use solar technology when my financial condition is } \\
\text { possible. }\end{array}$ & 0.979 \\
\hline STA3 & I would try to use solar technology at my business in the future & 0.907 \\
\hline STA4 & $\begin{array}{l}\text { Ideally, I would use solar technology at my business to supply a } \\
\text { portion of energy usage }\end{array}$ & 0.961 \\
\hline STA5 & $\begin{array}{l}\text { I predict that more small businesses will use solar technology than } \\
\text { stand-alone generator soon }\end{array}$ & 0.906 \\
\hline
\end{tabular}

Standardized Factor

Loadings

0.986

Estimate:

Table 4. Statistical results for evaluating the overall model goodness of fit extracted (AMOS-23)

\begin{tabular}{cllllllll}
\hline \multicolumn{7}{c}{ The Overall Goodness of Fit Model Criteria and Results } \\
\hline & Absolute & \multicolumn{5}{c}{ Relative } & \multicolumn{3}{c}{ Parsimonious } \\
\hline Indices & Criteria & Results & Indices & Criteria & Results & Indices & Criteria & Results \\
& Value & & & Value & & & Value & \\
\hline Chi-square & $\mathrm{p}>0.05$ & $\mathbf{0 . 0 0 0}$ & CFI & $>0.90$ & $\mathbf{0 . 9 5 9}$ & PCFI & $>0.50$ & $\mathbf{0 . 8 1 2}$ \\
CMIN/DF & $<5.0$ & $\mathbf{3 . 4 9 1}$ & NFI & $>0.90$ & $\mathbf{0 . 9 4 3}$ & PNFI & $>0.50$ & $\mathbf{0 . 7 9 9}$ \\
GFI & $>0.90$ & $\mathbf{0 . 9 9 6}$ & IFI & $>0.90$ & $\mathbf{0 . 9 5 9}$ & & & \\
AGFI & $>0.80$ & $\mathbf{0 . 9 9 5}$ & RFI & $>0.90$ & $\mathbf{0 . 9 3 3}$ & & & \\
RMSEA & $<0.10$ & $\mathbf{0 . 0 7 9}$ & & & & & & \\
SRMR & $<0.08$ & $\mathbf{0 . 0 4 2}$ & & & & & & \\
RMR & $<0.08$ & $\mathbf{0 . 0 4 0}$ & & & & & & \\
\hline
\end{tabular}

Source: Goodness of Fit Criteria Adapted from Meyers et al. (2016, p. 559): Applied Multivariate Research: Design and Interpretation

\section{Results}

\subsection{Descriptive Results: Demographic Profile}

Out of the 400 samples analyzed, $41.3 \%$ were both manager and owner of their businesses which are mostly service business (50.8\%). Most of the respondents age ranged from 41 to 50 years of age (34\%) and between 31 to 40 (28\%) respectively. The gender was proportionately distributed with males slightly higher $(54.3 \%)$ and female (45.8\%). Regarding the business size, most of the managers (owners) are micro see (table 2.1) business with less than 10 employees (72.3\%) and they mostly use stand-alone generator and national grid (PHCN) electricity as their main source of power. Additionally, the experience as how long they have been in business is mostly 1 to 10 years $(48.5 \%)$ and 11 to 20 years $(39.5 \%)$ respectively. 
Table 5. Respondents profile

\begin{tabular}{|c|c|c|c|}
\hline Variable & Classification of Variable & Frequency & Percent (\%) \\
\hline \multirow{5}{*}{ Type of Business } & Manufacturing & 71 & 17.8 \\
\hline & Service & 203 & 50.8 \\
\hline & Wholesale and Retail trade & 117 & 29.3 \\
\hline & Other & 9 & 2.3 \\
\hline & Total & 400 & 100.0 \\
\hline \multirow[t]{5}{*}{ Position } & Manager & 75 & 18.8 \\
\hline & Owner & 155 & 38.8 \\
\hline & Both the manager and owner & 165 & 41.3 \\
\hline & Other & 5 & 1.3 \\
\hline & Total & 400 & 100.0 \\
\hline \multirow[t]{3}{*}{ Gender } & Male & 217 & 54.3 \\
\hline & Female & 183 & 45.8 \\
\hline & Total & 400 & 100.0 \\
\hline \multirow{4}{*}{ Business Size } & Less than 10 & 289 & 72.3 \\
\hline & $11-49$ & 103 & 25.8 \\
\hline & $50-199$ & 8 & 2.0 \\
\hline & Total & 400 & 100.0 \\
\hline \multirow[t]{6}{*}{ Age } & $20-30$ & 56 & 14.0 \\
\hline & $31-40$ & 112 & 28.0 \\
\hline & $41-50$ & 136 & 34.0 \\
\hline & $51-60$ & 80 & 20.0 \\
\hline & Above 61 & 16 & 4.0 \\
\hline & Total & 400 & 100.0 \\
\hline \multirow[t]{4}{*}{$\begin{array}{l}\text { Current Source of } \\
\text { Electricity }\end{array}$} & $\begin{array}{l}\text { Stand-alone fuel generator and } \\
\text { PHCN electricity }\end{array}$ & 343 & 85.8 \\
\hline & PHCN electricity & 37 & 9.3 \\
\hline & Other & 20 & 5.0 \\
\hline & Total & 400 & 100.0 \\
\hline \multirow{6}{*}{$\begin{array}{l}\text { Experience as how } \\
\text { long they have } \\
\text { been in business }\end{array}$} & $1-10$ & 194 & 48.5 \\
\hline & $11-20$ & 158 & 39.5 \\
\hline & $21-30$ & 40 & 10.0 \\
\hline & $31-40$ & 5 & 1.3 \\
\hline & Over 41 & 3 & .8 \\
\hline & Total & 400 & 100.0 \\
\hline
\end{tabular}

\subsection{Measurement and Structural Models Estimation}

After testing the overall goodness of fit for the model i.e. the confirmatory factor analysis (CFA: standardized factors loadings of the observed variables above 0.5 was retained for further analysis, whereas the observed variables below 0.5 was dropped) see Table.3, the AVE and CR as depicted in Figure.4, the model fitness indices indicated either good or excellent fit, therefore, the model fitted well for the data. Graphic Software of AMOS-23 was used to analyze the data and perform the structural equation modeling (SEM). Additionally, the structural model estimation validates the relationship between the dependent variable of research (solar technology adoption intention) and the independent variables of awareness-knowledge, attitude, opportunities, barrier and DIA. As shown in Table.4, apart from chi-square significant indicator that lacks a goodness of fit which is sensitive to sample size, the model passed the overall goodness of fit based on other criteria. The results showed that the five independent variables explained approximately $71 \%$ of the variances of solar technology adoption intention (Fig.6). As depicted in Table.6, eight hypotheses were statistically significant based on Beta and significance value, thus, were accepted. However, three other hypotheses were not statistically significant. 


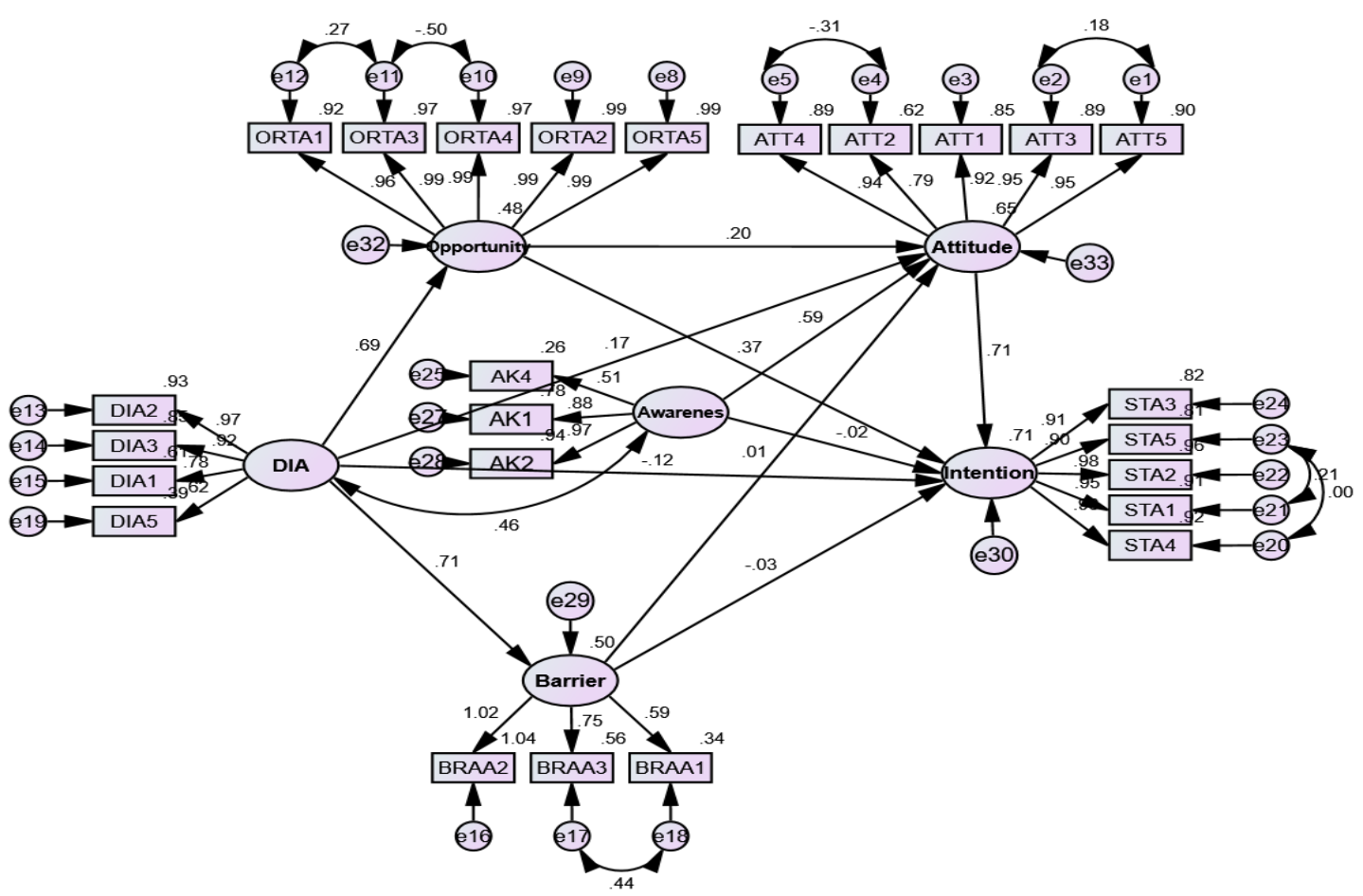

Figure 6. Hypothesized model standardized result extracted (AMOS-23)

Note: Goodness-of-fit statistics: Relative chi-square $=3.491$; GFI $=0.996$, AGFI $=0.995, \mathrm{CFI}=0.959$, IFI $=0.959$, $\mathrm{PCFI}=0.812, \mathrm{PNFI}=0.799, \mathrm{RMSEA}=0.079, \mathrm{SRMR}=0.042, \mathrm{RMR}=0.040$.

Table 6. The summary of results from the hypothesis testing extracted (AMOS-23)

\begin{tabular}{|c|c|c|c|c|}
\hline Hypotheses & Statements & $\begin{array}{l}\text { Standardized } \\
\text { Estimates }(\beta)\end{array}$ & Significance & Findings \\
\hline $\mathbf{H}_{1}$ & $\begin{array}{l}\text { Manager's (Owner's) mindset/attitude has } \\
\text { a significant positive effect on solar } \\
\text { technology adoption intention }\end{array}$ & 0.705 & $* * *$ & Supported \\
\hline $\mathbf{H}_{2 \mathbf{a}}$ & $\begin{array}{l}\text { There is a positive relationship between } \\
\text { opportunities and manager's (owner's) } \\
\text { mindset/attitude towards solar technology }\end{array}$ & 0.203 & $* * *$ & Supported \\
\hline $\mathbf{H}_{2 b}$ & $\begin{array}{l}\text { There is a negative relationship between } \\
\text { barriers and manager's (owner's) } \\
\text { mindset/attitude towards solar technology }\end{array}$ & 0.014 & 0.754 & $\begin{array}{c}\text { Not } \\
\text { Supported }\end{array}$ \\
\hline $\mathbf{H}_{3 \mathbf{a}}$ & $\begin{array}{l}\text { There is a positive relationship between } \\
\text { opportunities and solar technology } \\
\text { adoption intention }\end{array}$ & 0.373 & $* * *$ & Supported \\
\hline $\mathbf{H}_{3 b}$ & $\begin{array}{l}\text { There is a negative relationship between } \\
\text { barriers and solar technology adoption }\end{array}$ & -0.031 & 0.449 & $\begin{array}{c}\text { Not } \\
\text { Supported }\end{array}$ \\
\hline $\mathbf{H}_{4 a}$ & $\begin{array}{l}\text { Disruptive innovation activities have a } \\
\text { positive relationship opportunities }\end{array}$ & 0.694 & $* * *$ & Supported \\
\hline $\mathbf{H}_{4 \mathrm{~b}}$ & $\begin{array}{l}\text { Disruptive innovation activities have a } \\
\text { negative relationship with barriers }\end{array}$ & 0.709 & $* * *$ & Supported \\
\hline $\mathbf{H}_{5}$ & $\begin{array}{l}\text { Disruptive innovation activities have a } \\
\text { significant positive effect on solar } \\
\text { technology adoption intention }\end{array}$ & -0.124 & $0.017^{* *}$ & Supported \\
\hline $\mathrm{H}_{6}$ & $\begin{array}{l}\text { Disruptive innovation activities have a } \\
\text { positive relationship with manager's } \\
\text { (owner's) mindset/attitude towards solar }\end{array}$ & 0.17 & $0.003^{* *}$ & Supported \\
\hline
\end{tabular}




\begin{tabular}{|c|c|c|c|c|}
\hline Hypotheses & Statements & $\begin{array}{l}\text { Standardized } \\
\text { Estimates }(\beta)\end{array}$ & Significance & Findings \\
\hline $\mathbf{H}_{7}$ & $\begin{array}{l}\text { technology } \\
\text { Awareness-Knowledge has a positive } \\
\text { relationship with manager's (owner's) } \\
\text { mindset/attitude towards solar technology }\end{array}$ & 0.589 & $* * *$ & Supported \\
\hline $\mathbf{H}_{8}$ & $\begin{array}{l}\text { Awareness-Knowledge has a significant } \\
\text { positive effect solar technology adoption } \\
\text { intention }\end{array}$ & -0.019 & 0.677 & $\begin{array}{c}\text { Not } \\
\text { Supported }\end{array}$ \\
\hline
\end{tabular}

Note: Significance of regression weight: $\dagger \mathrm{p}<0.100,{ }^{*} \mathrm{p}<0.050,{ }^{* *} \mathrm{p}<0.010,{ }^{* * *} \mathrm{p}<0.001$ two-tailed

\section{Discussion and Conclusion}

The importance of solar technology (Photovoltaic systems- PV) as a viable alternative to mitigate the problem of power shortages cannot be overemphasized because of the vital role of necessity it intends to play for business activities and everyday lives in Nigeria. More than 620 million people have been estimated in Sub-Saharan Africa to have no access to steady and uninterrupted electricity for business or households' purposes (An African Energy Industry Report, $2018^{6}$ ) hence, the insights from this study can be used in the Nigerian context as well as other African nations with similar power predicaments. This study contributes not only by strengthening the existing literature in solar technology adoption but also provides planners and policy-makers with relevant information for developing renewable energy policy for MSMEs in Nigeria. This study argued that solar technology can disrupt the energy sector particularly, the fossil fuel stand-alone generators in Nigeria because of the benefits of solar technology as mentioned earlier. Therefore, this study examined the factors influencing managers (owners) of MSMEs intention to adopt solar technology because of the important role that MSMEs plays in the economy.

According to the result, $\mathbf{H}_{\mathbf{1}}$ was supported $(\beta=0.705 ; \mathrm{p}<0.001)$, attitude has a significant positive effect on solar technology adoption intention. The findings are consistent with the previous research (Jorns, 2020; Kim et al., 2014; Park \& Ohm, 2014). This means that managers (owners) have a positive mindset about solar technology and if given the opportunity, they intend to adopt solar technology. Evidently, from the results of the data analysis, $\mathbf{H}_{2 \mathbf{a}}$ opportunities positively impacted the manager's (owner's) mindset/attitude towards solar technology $(\beta=0.203 ; \mathrm{p}<0.001)$ hence, was confirm and supported. Previous studies confirm these results (for instance, Ajah, 2019; Caird et al., 2008; Loveldy et al., 2021; Mills \& Schleich, 2012; Parsad et al., 2020; Walters et al., 2018) suggested that government policy support creates an environment that managers (owners) of MSMEs perceived as opportunities which activates their reason to adopt solar technology. Additional, perceived benefits of the new technology in terms of functionality, independent from national grid, efficiency and effectiveness in improving business activities impacted their attitude towards solar technology. However, $\mathbf{H}_{\mathbf{2 b}}$ result indicated that barrier (reasons against adoption) has no statistical significance at $(\beta=0.014 ; p>0.05)$, therefore, $\mathbf{H}_{\mathbf{2 b}}$ was rejected. This indicated that managers (owners) of MSMEs perceived lack of government support policies creating environmental barrier and perceived cost does not negatively influence their mindset/attitude towards solar technology. The result does not conform to Claudy et al. (2015) however, the authors stated that reason for and against adoption as barrier influences buyer's decisions in a dissimilar way and it has significant implications for managers and other stakeholders, this happens because, reasons for and against solar technology adoption are not contrasting, but they are different constructs which influences managers (owners) mindset/attitude towards solar adoption in different ways. Also, the result does not align with (Parsad et al., 2020; Reddy \& Painuly, 2004) that found barriers (e.g., financial barrier) to influence attitude and solar technology adoption intention and Loveldy et al. (2021) findings that suggested the reasons against adoption significantly impact mindset/attitude towards solar technology. The reason may be because of the differences in the unit of analysis, most of the previous studies are based on households whereas, this study is on MSMEs. The business usage and purpose differs from households and the availability of the national grid, the environmental concern issues differs in different context. $\mathbf{H}_{3 \mathbf{a}}$ result revealed that there is a statistical significant positive relationship between opportunities and solar technology adoption intention $(\beta=0.373 ; \mathrm{p}<0.001)$ and was sustained. It implied managerially that when managers (owners) of MSMEs perceived benefits concerning solar technology is positive, they tend to see the new technology as an opportunity to be exploited and therefore, as expected, it influences their solar technology adoption intention. This result aligned with the findings of previous studies like (Board, 2020; Claudy et al., 2015; Kim et al., 2014; Parsad

\footnotetext{
${ }^{6}$ https://africa-energy-portal.org/reports/african-energy-industry-report-2018 (Accessed October 29, 2021)
} 
et al., 2020; Walters et al., 2018). $\mathbf{H}_{\mathbf{3 b}}$ was rejected $(\beta=-0.031 ; \mathrm{p}>0.05)$, this meant that manager (owners) of MSMEs perceived lack of government policy support barrier and the perceived initial cost and maintenance cost does not negatively influence solar technology adoption intention. Essentially, perceived barrier would not reduce the tendency for managers (owners) of MSMEs solar technology adoption intention. The suggestion is that, even when solar technology is being perceived as expensive innovation, it does not impact the adoption intention. This findings does not complement the findings of the previous literatures for instance, (Abdullahi et al., 2021; Board, 2020; Caird et al., 2008; Kim et al., 2014; Loveldy et al., 2021; Parsad et al., 2020; Walters et al., 2018) found financial barrier and or perceived cost to significantly influence intention to adopt solar technology. Again, the reasons might be because the differences in the unit of analysis, usage purpose differs from businesses and households and the availability of the national grid, the environmental concern issues differs in different context.

$\mathbf{H}_{4 \boldsymbol{a}}$ was supported ( $\beta=0.694 ; \mathrm{p}<0.001$ ), it suggested that managers (owners) of MSMEs who are more interested in trying new technology (solar technology) to improve their business efficiency and effectiveness do so base on their perceived benefits that the new technology will bring to their business, so they exploit the DIA process. This result aligned with previous studies results (e.g., J. Chen et al., 2017) which postulated that managers (owners) innovation willingness promotes low end disruptive innovation. They advocated that managers (owners) of SMEs who are positively inclined towards innovative product pays more attention to the innovation and invest more on such innovation. Similarly, $\mathbf{H}_{\mathbf{4 b}}$ was confirmed and supported $(\beta=0.709 ; p<0.001)$, the findings suggested that managers (owners) of MSMEs DIA negatively influence their perceived lack of government support policies creating environmental barrier as well as perceived cost. This means, even if the managers (owners) intends to adopt solar technology to improve their business efficiency, they are worried about the barrier. This might hinder the DIA process, even if managers (owners) that are technologically inclined tends not to adopt solar technology when the perceived barrier is high. In order words, DIA would reduce the propensity of managers (owners) of MSMEs perceived barrier. The result of this study conform with J. Chen et al. (2017) empirical findings that suggested that barrier (lack government support) is a key factors influencing high end disruptive innovation in SMEs in China. The result of $\mathbf{H}_{5}$ was supported $(\beta=-0.124 ; \mathrm{p}<0.05)$, it suggested that managers (owners) of MSMEs who are more inclined towards innovative products for their business efficiency tends to have intention to adopt solar technology. This findings complimented the finding of (Goodstein \& Lovins, 2019) which suggested that for economic reasons particularly for MSMEs, solar technology will provide around $50 \%$ of electric power generation globally by the year 2030. It also complemented the findings of (Osiyevskyy \& Dewald, 2015) and (Habtay, 2012) that stated that technology is not disruptive on its own but the disruptive personality of managers in capturing and taking the opportunity of the technology to improve a business model drives the adoption intention. The result of $\mathbf{H}_{\mathbf{6}}$ was supported $(\beta=0.17 ; \mathrm{p}<0.010)$, the findings denoted that manager (owners) DIA influences their attitude and behavior with regards to solar technology. It signified that manager (owners) of MSMEs who are motivated towards innovative products like solar tends to have a positive attitude towards solar technology. Concurring to this findings, Thompson, Ajiboye, Oluwamide, and Oyenike (2021) found the attributes of solar technology makes it attractive and one of the reasons the respondents preferred solar technology. The attributes which includes availability, affordability and accessibility could trigger DIA process based on mangers (owners) mindset/attitude towards solar technology. $\mathbf{H}_{7}$ was also supported $(\beta=0.589 ; \mathrm{p}<0.001)$ and in agreement with Rezaei and Ghofranfarid (2018) findings, however, $\mathbf{H}_{\mathbf{8}}$ was not supported $(\beta=-0.019 ; \mathrm{p}>.05)$. This indicated that managers (owners) awareness-knowledge about solar technology significantly influence manager's (owner's) mindset/attitude towards solar technology as found in $\mathbf{H}_{\mathbf{7}}$ but not necessarily transpiring to adoption intention of solar technology. The reason may be because, managers (owners) are aware of the benefits of the technology for their business and have a good knowledge about its functions but are concerned about the barriers associated with the technology such as; lack of incentives from government in Nigeria context as evidenced by (Ebitu et al., 2016), perceived initial and maintenance cost etc. and this might dissuade them from having a positive intention to adopt solar technology.

\section{Limitations}

This study is a case study of Lagos State in Nigeria which suggests that the analysis of the result may be difficult to generalize, therefore, future studies may explore different states and or adopt a comparative model in terms of solar renewable energy technology in different African nations for more improved discoveries. Moreover, this study utilized quantitative method with a proposed conceptual model, hence, there is a possibility that a number of essential variable and relationships were missed in the research model. Lastly, a mixed method approach with different samples quantitatively and qualitative data obtained from interviews or focus group discussion is important for a more composed results and imperative implications. 


\section{Recommendations as Practical Contribution}

According to African Energy Industry Report ${ }^{7}$, between 2015 and 2030 the economic growth in Africa is predicted at 7\% per year on average but the growth will vary across five African regions. For these forecast to materialized in Africa, Nigeria in this context needs to restructure its energy policy by deploying modern renewable energy technologies to eradicate power supply shortages. There is no sustainable development without an energy mix. As identified earlier, economic sustainable development depends on a mixed energy sources. An increase in economic activities spur industrial growth through MSMEs and entrepreneurs which brings sustainable development and reduces poverty. However, these are all dependent on the policy choices and political will of the government as well as non-governmental organizations that plays a vital role in energy sector in Nigeria as depicted in Table 2. The potential of solar technology to transform Nigeria's industrial sector and creating economic competitiveness of MSMEs is critical because of the importance of a reliable and affordable energy for this business sector that have been pushed to resorting to expensive diesel stand-alone generators for power source. Therefore, it is recommended that the government of Nigeria and other stakeholder do the following based on the results of this research:

Table 7. Proposed solar energy policy options and actions

\begin{tabular}{ll}
\hline Energy source & \multicolumn{1}{c}{ Recommendations as Practical Contribution to the Government } \\
\hline - Develop policy that integrates solar technology into the energy master plan and \\
prioritize it because of its ease of use and immediate impact on MSMEs \\
- There is discrepancy in the messaging about the available policies and its intended \\
benefits to end users and suppliers as evidenced in the results of this research, therefore, \\
the government and its agencies should create awareness on renewable energy and \\
communicate the benefits as well as the incentives available to potential users if any to \\
reduce the perceived barrier
\end{tabular}

- A clear and comprehensible energy policy that guides the MSMEs and citizens towards solar technology to harness as an efficient energy resources and viable alternative for power shortages

- Creating and promoting energy-efficient policies among the manufacturing \& installation (suppliers) companies of energy generation that will attract FDI

- Government should encourage investors through fiscal and financial incentives

- Solar technology policies should target MSMEs for commercial purposes the same way it has concentrated on households implementation

- Government should establish a solar technology energy funding (financing)

\section{Solar Technology: Renewable Energy}

\section{Recommendations as Practical Contribution to the Business, Donors and NGO}

- There have been a tremendous support from the international community to empower Africa and women through solar technology for instance, the USaid.gov

- However, creating and establishing manufacturing based in Nigeria and utilizing the talents will make an additional impact in economic sustainable development and poverty eradication

- This is similar to what South Africa laboratory for renewable energy technologies provides and could be replicated in a massive scale to make impact by equipping African people to be able to stand on their own

- Businesses and NGO's should create a platform integration of renewable energy systems and partner with MSMEs directly rather than working with only government agencies to facilitate creative awareness for adoption

- The manufacturing \& installation (suppliers) companies should train qualified installers, designers, electricians etc. who work in the solar system supply chain and provide technical advice to solar technology adopters

\footnotetext{
${ }^{7}$ https://africa-energy-portal.org/sites/default/files/2018-10/1-mir-africa-mir-18-2-es_685804715-05-2018.pdf
} 
Recommendations as Practical Contribution to the Academics/Academia's

- More research is needed in the area of solar technology and the motivational factors for potential adopter to recommend to stakeholders

- There is also a necessity to research solar adoption on MSMEs particularly as most of the research are based on household's usage. There is significant difference between business and households' usage as found in this research, however, more studies in different context is needed

- Additionally, exploring solar renewable energy adoption through the lens of DIA and in different context is an area that require more attention in the literature

\section{References}

Abdullahi, D., Renukappa, S., Suresh, S., \& Oloke, D. (2021). Barriers for implementing solar energy initiatives in Nigeria: an empirical study. Smart and Sustainable Built Environment. https://doi.org/10.1108/SASBE-062020-0094

Ajah, S. N. (2019). Solar Energy: A Source of Renewable Energy and a Disruptive Innovation Creating Business Opportunities in Nigeria. Human Behavior, Development and Society, Vol 20 No 3, 84-94.

Ajzen, I., \& Fishbein, M. (2005). The influence of attitudes on behavior.

Alabi, O., Ackah, I., \& Lartey, A. (2017). Re-visiting the renewable energy-economic growth nexus: Empirical evidence from African OPEC countries. International Journal of Energy Sector Management. https://doi.org/10.1108/IJESM-07-2016-0002

Alam, S. S., Hashim, N. H. N., Rashid, M., Omar, N. A., Ahsan, N., \& Ismail, M. D. (2014). Small-scale households renewable energy usage intention: Theoretical development and empirical settings. Renewable energy, 68, 255-263. https://doi.org/10.1016/j.renene.2014.02.010

Aliyu, A. S., Dada, J. O., \& Adam, I. K. (2015). Current status and future prospects of renewable energy in Nigeria. Renewable and Sustainable Energy Reviews, 48, 336-346. https://doi.org/10.1016/j.rser.2015.03.098

Amuzu-Sefordzi, B., Martinus, K., Tschakert, P., \& Wills, R. (2018). Disruptive innovations and decentralized renewable energy systems in Africa: A socio-technical review. Energy research \& social science, 46, 140154. https://doi.org/10.1016/j.erss.2018.06.014

Assembly, G. (2015). Resolution adopted by the General Assembly on 11 September 2015. Retrieved from

Babbie, E. (2013). The practice of social research (International Edition). Andover: Cengage Learning.

Bachtiar, M. (2006). Prosedur perancangan sistem pembangkit listrik tenaga surya untuk perumahan (solar home system). SMARTek, 4(3).

Bazmi, A. A., \& Zahedi, G. (2011). Sustainable energy systems: Role of optimization modeling techniques in power generation and supply-A review. Renewable and Sustainable Energy Reviews, 15(8), 3480-3500. https://doi.org/10.1016/j.rser.2011.05.003

Bell, E., Bryman, A., \& Harley, B. (2018). Business research methods: Oxford university press.

Board, C. E. (2020). Impact of Perceived Ease of Use, Awareness and Perceived Cost on Intention to Use Solar Energy Technology in Sri Lanka. Journal of International Business and Management, 3(4), 01-13.

Bryman, A. (2006). Integrating quantitative and qualitative research: how is it done? Qualitative research, 6(1), 97-113. https://doi.org/10.1177/1468794106058877

Caird, S., Roy, R., \& Herring, H. (2008). Improving the energy performance of UK households: Results from surveys of consumer adoption and use of low-and zero-carbon technologies. Energy Efficiency, 1(2), 149. https://doi.org/10.1007/s12053-008-9013-y

Chen, J., Zhu, Z., \& Zhang, Y. (2017). A study of factors influencing disruptive innovation in Chinese SMEs. Asian Journal of Technology Innovation, 25(1), 140-157. https://doi.org/10.1080/19761597.2017.1302552

Chen, K. K. (2014). Assessing the effects of customer innovativeness, environmental value and ecological lifestyles on residential solar power systems install intention. Energy Policy, 67, 951-961. https://doi.org/10.1016/j.enpol.2013.12.005 
Christensen, C. M., \& Bower, J. L. (1996). Customer power, strategic investment, and the failure of leading firms. Strategic management journal, 17(3), 197-218. https://doi.org/10.1002/(SICI)10970266(199603)17:3<197::AID-SMJ804>3.0.CO;2-U

Claudy, M. C., Garcia, R., \& O’Driscoll, A. (2015). Consumer resistance to innovation-a behavioral reasoning perspective. Journal of the Academy of Marketing Science, 43(4), 528-544. https://doi.org/10.1007/s11747014-0399-0

Claudy, M. C., Peterson, M., \& O'driscoll, A. (2013). Understanding the attitude-behavior gap for renewable energy systems using behavioral reasoning theory. Journal of Macromarketing, 33(4), 273-287. https://doi.org/10.1177/0276146713481605

Creswell, J. W., \& Creswell, J. D. (2017). Research design: Qualitative, quantitative, and mixed methods approaches: Sage publications.

Doe, F., \& Emmanuel, S. E. (2014). The effect of electric power fluctuations on the profitability and competitiveness of SMEs: A study of SMEs within the Accra Business District of Ghana. Journal of Competitiveness, 6(3). https://doi.org/10.7441/joc.2014.03.03

Ebitu, E. T., Glory, B., \& Alfred, U. J. (2016). An appraisal of Nigeria's micro, small and medium enterprises (MSMEs): Growth, challenges and prospects. British Journal of Marketing Studies, 4(5), 21-36.

Efurumibe, E. (2013). Barriers to the development of renewable energy in Nigeria. Scholarly Journal of Biotechnology, 2, 11-13.

Emodi, N. V., \& Ebele, N. E. (2016). Policies enhancing renewable energy development and implications for Nigeria. Sustain Energy, 4(1), 7-16. https://doi.org/10.9734/BJECC/2016/24628

Europe, G. m. o. (2017). Global market outlook for solar power 2017-2021. SolarPower Eur, 60.

Ezennaya, O., Isaac, O., Okolie, U., \& Ezeanyim, O. (2014). Analysis of Nigeria's national electricity demand forecast (2013-2030). International Journal of Science and Technology Research, 3(3), 333-340.

Faiers, A. (2009). Understanding the Adoption of Solar Power Technologies in the UK Domesic Sector. Cranfield University, School of Applied Sciences,

Gaskin, J., \& Lim, J. (2016). Master validity tool. AMOS Plugin In: Gaskination’s StatWiki.

Goodstein, E., \& Lovins, L. H. (2019). A pathway to rapid global solar energy deployment? Exploring the solar dominance hypothesis. Energy research \& social science, 56, 101197. https://doi.org/10.1016/j.erss.2019.05.007

Guzmán - Alfonso, C., \& Guzmán - Cuevas, J. (2012). Entrepreneurial intention models as applied to Latin America. Journal of Organizational Change Management. https://doi.org/10.1108/09534811211254608

Habtay, S. R. (2012). A firm - level analysis on the relative difference between technology - driven and market driven disruptive business model innovations. Creativity and Innovation Management, 21(3), 290-303. https://doi.org/10.1111/j.1467-8691.2012.00628.x

Hai, M. (2021). SOOCIAL ACCEPTANCE OF SOLAR ENERGY AS INTENTION, WILLINGNESS, AND READINESS.

Hair Jr, J. F., Hult, G. T. M., Ringle, C. M., \& Sarstedt, M. (2021). A primer on partial least squares structural equation modeling (PLS-SEM): Sage publications. https://doi.org/10.1007/978-3-030-80519-7

Hu, L. t., \& Bentler, P. M. (1999). Cutoff criteria for fit indexes in covariance structure analysis: Conventional criteria versus new alternatives. Structural equation modeling: a multidisciplinary journal, 6(1), 1-55. https://doi.org/10.1080/10705519909540118

Jorns, A. R. (2020). Smallholder farmers ' perceptions toward solar renewable energy technology on the island of Trinidad. The Ohio State University,

Kim, H., Park, E., Kwon, S. J., Ohm, J. Y., \& Chang, H. J. (2014). An integrated adoption model of solar energy technologies in South Korea. Renewable energy, 66, 523-531. https://doi.org/10.1016/j.renene.2013.12.022

Kline, R. B. (2015). Principles and practice of structural equation modeling: Guilford publications.

Loveldy, Z. A. C., Ismail, T. A. T., \& Jubaedah, S. S. (2021). Examining the Attitude-Behavior Gap and Adoption Intention of SHS Technology: The Role of Social Influence. International Journal of Applied Business Research, 14-24. https://doi.org/10.35313/ijabr.v3i1.119 
LTD, O. C. (2006). Policies for Energy Efficiency in the UK Household Sector. Oxera. In: Oxford.

Mahalanobis, P. C. (1936). On the generalized distance in statistics.

McDonald, S., Gan, B. C., Fraser, S. S., Oke, A., \& Anderson, A. R. (2015). A review of research methods in entrepreneurship 1985-2013. International Journal of Entrepreneurial Behavior \& Research. https://doi.org/10.1108/IJEBR-02-2014-0021

Meyers, L. S., Gamst, G., \& Guarino, A. J. (2016). Applied multivariate research: Design and interpretation: Sage publications.

Mills, B., \& Schleich, J. (2012). Residential energy-efficient technology adoption, energy conservation, knowledge, and attitudes: An analysis of European countries. Energy Policy, 49, 616-628. https://doi.org/10.1016/j.enpol.2012.07.008

Mkhwanazi, X. (2003). Power sector development in Africa. Paper presented at the The Workshop for African Energy Experts on Operationalizing the NEPAD Energy Initiative.

Muza, O., \& Debnath, R. (2021). Disruptive innovation for inclusive renewable policy in sub-Saharan Africa: A social shaping of technology analysis of appliance uptake in Rwanda. Renewable energy, 168, 896-912. https://doi.org/10.1016/j.renene.2020.12.091

Ohunakin, O. S., Adaramola, M. S., Oyewola, O. M., \& Fagbenle, R. O. (2014). Solar energy applications and development in Nigeria: Drivers and barriers. Renewable and Sustainable Energy Reviews, 32, 294-301. https://doi.org/10.1016/j.rser.2014.01.014

Osiyevskyy, O., \& Dewald, J. (2015). Explorative versus exploitative business model change: the cognitive antecedents of firm - level responses to disruptive innovation. Strategic Entrepreneurship Journal, 9(1), 5878. https://doi.org/10.1002/sej.1192

Oyedepo, S. O. (2014). Towards achieving energy for sustainable development in Nigeria. Renewable and Sustainable Energy Reviews, 34, 255-272. https://doi.org/10.1016/j.rser.2014.03.019

Ozoegwu, C., Mgbemene, C., \& Ozor, P. A. (2017). The status of solar energy integration and policy in Nigeria. Renewable and Sustainable Energy Reviews, 70, 457-471. https://doi.org/10.1016/j.rser.2016.11.224

Park, E., \& Ohm, J. Y. (2014). Factors influencing the public intention to use renewable energy technologies in South Korea: Effects of the Fukushima nuclear accident. Energy Policy, 65, 198-211. https://doi.org/10.1016/j.enpol.2013.10.037

Parsad, C., Mittal, S., \& Krishnankutty, R. (2020). A study on the factors affecting household solar adoption in Kerala, India. International Journal of Productivity and Performance Management. https://doi.org/10.1108/IJPPM-11-2019-0544

Paul, D. I., \& Uhomoibhi, J. (2012). Solar power generation for ICT and sustainable development in emerging economies. Campus-Wide Information Systems. https://doi.org/10.1108/10650741211253813

Paul, D. I., \& Uhomoibhi, J. O. (2014). Generating solar electricity by solar concentrators for web-based learning in rural areas in Tanzania: Issues of practice and impacts. Paper presented at the 2014 International Conference on Interactive Collaborative Learning (ICL). https://doi.org/10.1109/ICL.2014.7017919

Petzold, N., Landinez, L., \& Baaken, T. (2019). Disruptive innovation from a process view: A systematic literature review. Creativity and Innovation Management, 28(2), 157-174. https://doi.org/10.1111/caim.12313

Reddy, S., \& Painuly, J. P. (2004). Diffusion of renewable energy technologies - barriers and stakeholders' perspectives. Renewable energy, 29(9), 1431-1447. https://doi.org/10.1016/j.renene.2003.12.003

Rezaei, R., \& Ghofranfarid, M. (2018). Rural households' renewable energy usage intention in Iran: Extending the unified theory of acceptance and use of technology. Renewable energy, 122, 382-391. https://doi.org/10.1016/j.renene.2018.02.011

Rogers, E., \& Shoemaker, F. (2001). Communication of Innovation (F. Karami \& M. Fanaei, Trans.). Shiraz: Shiraz University Press.[In Persian].

Sadiq, F., \& Hussain, T. (2018). Exploring the role of managers in nurturing disruptive innovations. Business and Economic Review, 10(4), 103-120. https://doi.org/10.22547/BER/10.4.5

Sadiq, F., Hussain, T., \& Naseem, A. (2020). Managers' disruptive innovation activities: the construct, measurement and validity. Management Decision. https://doi.org/10.1108/MD-08-2019-1047 
Sakolsatayatorn, P. (2018). Evaluating the effects of the socio-economic, environmental, and institutional factors on sustainable renewable energy policy development in Thailand.

Saunders, M., Lewis, P., \& Thornhill, A. (2016). Research methods for business students (Seventh). Nueva York: Pearson Education.

Schumpeter, J. A. (2017). The Theory of Economic Development: An Inquiry into Profits, Capita I, Credit, Interest, and the Business Cycle: Routledge. https://doi.org/10.4324/9781315135564

Schwarz, E. J., Wdowiak, M. A., Almer - Jarz, D. A., \& Breitenecker, R. J. (2009). The effects of attitudes and perceived environment conditions on students' entrepreneurial intent: An Austrian perspective. Education + Training. https://doi.org/10.1108/00400910910964566

Sheikh, N. J., Kocaoglu, D. F., \& Lutzenhiser, L. (2016). Social and political impacts of renewable energy: Literature review. Technological Forecasting and Social Change, 108, 102-110. https://doi.org/10.1016/j.techfore.2016.04.022

Siegel, J. J. (2003). What is an asset price bubble? An operational definition. European financial management, 9(1), 11-24. https://doi.org/10.1111/1468-036X.00206

SMEDAN. (2013). SMEDAN and National Bureau of statistics collaborative survey: Selected findings.

Stritih, U., Paksoy, H., Turgut, B., Osterman, E., Evliya, H., \& Butala, V. (2015). Sustainable energy management: Solar energy and thermal storage technologies in two Mediterranean countries. Management of Environmental Quality: An International Journal. https://doi.org/10.1108/MEQ-06-2013-0063

Suanmali, S., Kokuenkan, K., Lohananthachai, N., Kumpong, N., \& Suwatanapornchai, T. (2018). Factors affecting the willingness to pay for solar home systems: An empirical study in Bangkok, Nonthaburi, Pathum Thani, and Samut Prakan provinces, Thailand. AJMI-ASEAN Journal of Management and Innovation, 5(2), 63-76.

Taiwo, M. A., Ayodeji, A. M., \& Yusuf, B. A. (2012). Impact of small and medium enterprises on economic growth and development. American journal of business and management, 1(1), 18-22. https://doi.org/10.11634/21679606170644

Thomond, P., Herzberg, T., \& Lettice, F. (2003). Disruptive innovation: Removing the innovators dilemma. Paper presented at the British Academy of Management Annual Conference:'Knowledge into Practice.

Thompson, O. A., Ajiboye, B. O., Oluwamide, A. D., \& Oyenike, O. O. (2021). Analysis of Factors Influencing Households' Preference Level for Solar Energy in Urban Areas of Southwest Nigeria. International Journal of Energy Economics and Policy, 11(3), 468-476. https://doi.org/10.32479/ijeep.10001

Ugulu, A., \& Aigbayboa, C. (2019). Motives for solar photovoltaic (PV) adoption in urban Nigeria. Paper presented at the IOP Conference Series: Earth and Environmental Science. https://doi.org/10.1088/1755$1315 / 385 / 1 / 012012$

Walters, J. P., Kaminsky, J., \& Huepe, C. (2018). Factors influencing household solar adoption in Santiago, Chile. Journal of Construction Engineering and Management, 144(6), 05018004. https://doi.org/10.1061/(ASCE)CO.1943-7862.0001483

Wolske, K. S., Stern, P. C., \& Dietz, T. (2017). Explaining interest in adopting residential solar photovoltaic systems in the United States: Toward an integration of behavioral theories. Energy research \& social science, 25, 134-151. https://doi.org/10.1016/j.erss.2016.12.023

Yamane, T. (1967). Statistics: An introductory analysis. Retrieved from

Yergin, D. (2012). How is energy remaking the world? Foreign Policy(194), 60.

Zikmund, W. G., Babin, B., Carr, J., \& Griffin, M. (2003). Research methods. Health economics research method, 2.

\section{Copyrights}

Copyright for this article is retained by the author(s), with first publication rights granted to the journal.

This is an open-access article distributed under the terms and conditions of the Creative Commons Attribution license (http://creativecommons.org/licenses/by/4.0/). 